\title{
Article \\ Swelling Properties and Permeability of GMZ Bentonite-Sand Mixtures during Different Solutions Infiltration
}

\author{
Yu-Ping Wang ${ }^{1,2,3}$, Zhe Wang ${ }^{1,3, *}$, Yu Zhao ${ }^{1}$, Fa-Cheng Yi ${ }^{1,3}$ and Bao-Long Zhu ${ }^{4}$ \\ 1 School of Environment and Resource, Southwest University of Science and Technology, \\ Mianyang 621010, China; ypwang123@163.com (Y.-P.W.); zhaoyuswust@163.com (Y.Z.); \\ yfc66@163.com(F.-C.Y.) \\ 2 International Faculty of Applied Technology, Yibin University, Yibin 644000, China \\ 3 Laboratory of Nuclear Wastes and Environmental Safety, Southwest University of Science and Technology, \\ Mianyang 621010, China \\ 4 School of Civil Engineering and Architecture, Southwest University of Science and Technology, \\ Mianyang 621010, China; borlong@163.com \\ * Correspondence: swustgroup@163.com
}

\section{check for}

updates

Citation: Wang, Y.-P.; Wang, Z.; Zhao, Y.; Yi, F.-C.; Zhu, B.-L. Swelling Properties and Permeability of GMZ Bentonite-Sand Mixtures during Different Solutions Infiltration. Sustainability 2021, 13, 1622. https:/ / doi.org/10.3390/su13041622

Received: 26 December 2020

Accepted: 23 January 2021

Published: 3 February 2021

Publisher's Note: MDPI stays neutral with regard to jurisdictional claims in published maps and institutional affiliations.

Copyright: (c) 2021 by the authors. Licensee MDPI, Basel, Switzerland. This article is an open access article distributed under the terms and conditions of the Creative Commons Attribution (CC BY) license (https:/ / creativecommons.org/licenses/by/ $4.0 /)$.
Abstract: In China, Gaomiaozi (GMZ) bentonite is recognized as a barrier material for isolating nuclear waste. Different chemical solutions may change the hydraulic conductivity and swelling capacity of bentonite. Consequently, a series of swelling pressure and permeability experiments was carried out on bentonite-sand mixtures with various dry densities and infiltrating solutions. X-ray diffraction (XRD) and the field emission scanning electron microscope (FESEM) were carried out on the samples experiencing the tests to identify the influence of chemistry pore solutions upon the mineralogical and microstructure changes. The results show that the swelling pressure experienced rapid swelling, slow expansion, and the stable expansion stage for the specimens of infiltrating solutions except for $\mathrm{NaOH}$. For the specimens infiltrated with $\mathrm{NaOH}$ solutions, the swelling pressure experienced rapid increases, slow decreases, and a stable development stage. With hyper-alkaline and hyper-salinity infiltration, the swelling pressure decreased, and the permeability increased. In addition, swelling pressure attained stability more quickly on contact with hyper-alkaline and hyper-salinity solutions. Comparing the test results, the results indicate that the influence of $\mathrm{NaOH}$ on the expansion and permeability was higher than $\mathrm{NaCl}-\mathrm{Na}_{2} \mathrm{SO}_{4}$ at the same concentration.

Keywords: bentonite-sand mixture; dry density; infiltrating solution; expansion pressure; permeability coefficient; FESEM

\section{Introduction}

By the end of 2019, there are 443 nuclear reactors in operation in the world. The operation of nuclear power plants has effectively alleviated the huge pressure of energy shortages in China and also produced significant nuclear waste. How to safely dispose of these nuclear wastes, especially high-level waste (HLW), is an important issue of concern to all countries in the world. Among the numerous disposal schemes of HLW, deep geological disposal is a recognized solution for the management of more HLW, as recommended by the International Atomic Energy Agency (IAEA) [1]. Deep geological disposal has been widely accepted as a method for the isolation of HLW from our environment. More and deep studies are needed, including expansion pressure, hydraulic conductivity, engineering barrier stability, human activities, radionuclide migration, etc., to ensure that the biosphere can be protected from the pollution of radionuclides for a long period. That is, packaging containers of HLW are buried in the tunnels of a geologic body at a depth of several hundred meters below the Earth's surface [2]. The site of a deep geological repository has to ensure that the risks on account of long-term radionuclide transport and the thermo-hydro-mechanical—chemical processes of the site are minimal [3,4]. Bentonite is recognized as an appropriate buffer material thanks to its fine radioactive nuclide 
retardation ability, swelling, a better cation exchangeability, low hydraulic activity, and self-healing. $\mathrm{Na}^{+}$-bentonite has been considered as an ideal buffer material in many countries. A number of significant properties of bentonite and its mixtures have been verified by numerous researchers through experiments [5-9]. However, cement degradation may occur during the operation of the reservoir in the Beishan area, and groundwater may reach a high $\mathrm{pH}$ value. The permeation of pore water chemistry will weaken the swelling pressure of bentonite.

Many studies have investigated the influence of near-field groundwater chemical composition on the engineering properties of bentonite using simulated leachate. It is considered that the chemical composition of the solution has a certain attenuation effect on the expansibility, which is associated with the pore water chemistry, stress conditions, and bentonite properties. Zhu et al. confirmed that the permeability coefficient increases as the salinity of the solution increases [10]. Chen et al. found that an increase in alkaline solution concentration increases the permeability coefficient [11]. Ye et al. measured the permeability coefficient and swelling pressures of Gaomiaozi 01 (GMZ01) bentonite at different temperatures and reported markedly increased hydraulic conductivity at higher $\mathrm{pH}$ [12]. Studds et al. confirmed the salinity of solution on the expansion force of bentonite [13]. Karnland et al. drew a conclusion that MX-80 bentonite and a high concentration $\mathrm{NaOH}$ solution reduce the expansion force significantly [14].

It has been reported that the action of clay materials primarily depends on pore fluid, the amount and type of clay, and the physicochemical interaction in particles [15]. Lee et al. investigated the effect of dry density and solution salinity on the swelling pressure [16]. Sun et al. conducted swelling pressure tests on GMZ sodium bentonite saturated with a salt solution with different total dissolved solids (TDS) concentrations [17]. Karnland et al. found that a bentonite-sand mixture and $\mathrm{NaCl}$ solution gave rise to an increase in hydraulic conductivity and a decrease in the expansion force [18]. Zhang et al. studied $\mathrm{NaCl}-\mathrm{Na}_{2} \mathrm{SO}_{4}$ solutions of different TDS on the expandability of GMZ bentonite mixed with quartz and found the maximum expansion force had a linear reduction with increasing TDS [19]. Nakayama et al. measured the rate of dissolving montmorillonite with an alkaline solution tank [20]. More and more attention has been paid to the study of mineral substances, microstructure, permeability coefficient, and compressibility characteristics of GMZ bentonite [12,21-23].

It is known that the pore chemical solutions possibly affect the safety assessment of disposal repositories [24-27]. In this article, a home-designed device suitable for hyperalkaline infiltration is used, and a series of expansion and permeability experiments are conducted at the temperature of $30{ }^{\circ} \mathrm{C}$, with dry density $\left(1.7,1.8\right.$, and $\left.1.9 \mathrm{~g} / \mathrm{cm}^{3}\right)$ and infiltrating solutions (de-ionized (DI) water, simulated Baishan groundwater, $\mathrm{NaCl}-\mathrm{Na}_{2} \mathrm{SO}_{4}$ solutions, and $\mathrm{NaOH}$ solutions). X-ray diffraction (XRD) and the field emission scanning electron microscope (FESEM) tests are carried out to determine the variation in mineral component and microstructure of mixture.

\section{Experimental Investigation}

\subsection{Apparatus}

The setup for the multifunctional swelling permeability test system is shown in Figure 1. This test system included four parts, a pressure chamber, temperature control system, a data acquisition and monitoring system, a water/alkaline converter, and a pressure-volume controller. The pressure-volume controller (0-4 MPa) was used to exert hydraulic pressure. The water/alkaline converter included two sections, connect one end of a stainless steel pressure chamber and connect the other end of the controller. The pressure chamber system contained a basement, a sample ring, pressure chamber, a stainless piston, top cover, sealing system, and inlet/outlet system. The temperature control system consisted of a heating electrode, temperature controller, fan, and temperature sensor. The range of the temperature control system was from room temperature to $90{ }^{\circ} \mathrm{C}$, and the accuracy was $\pm 0.5^{\circ} \mathrm{C}$. The data acquisition and monitoring system were mainly composed 
of a swelling pressure sensor, displacement sensor, temperature transducer, humidity transducer, and water pressure sensor.

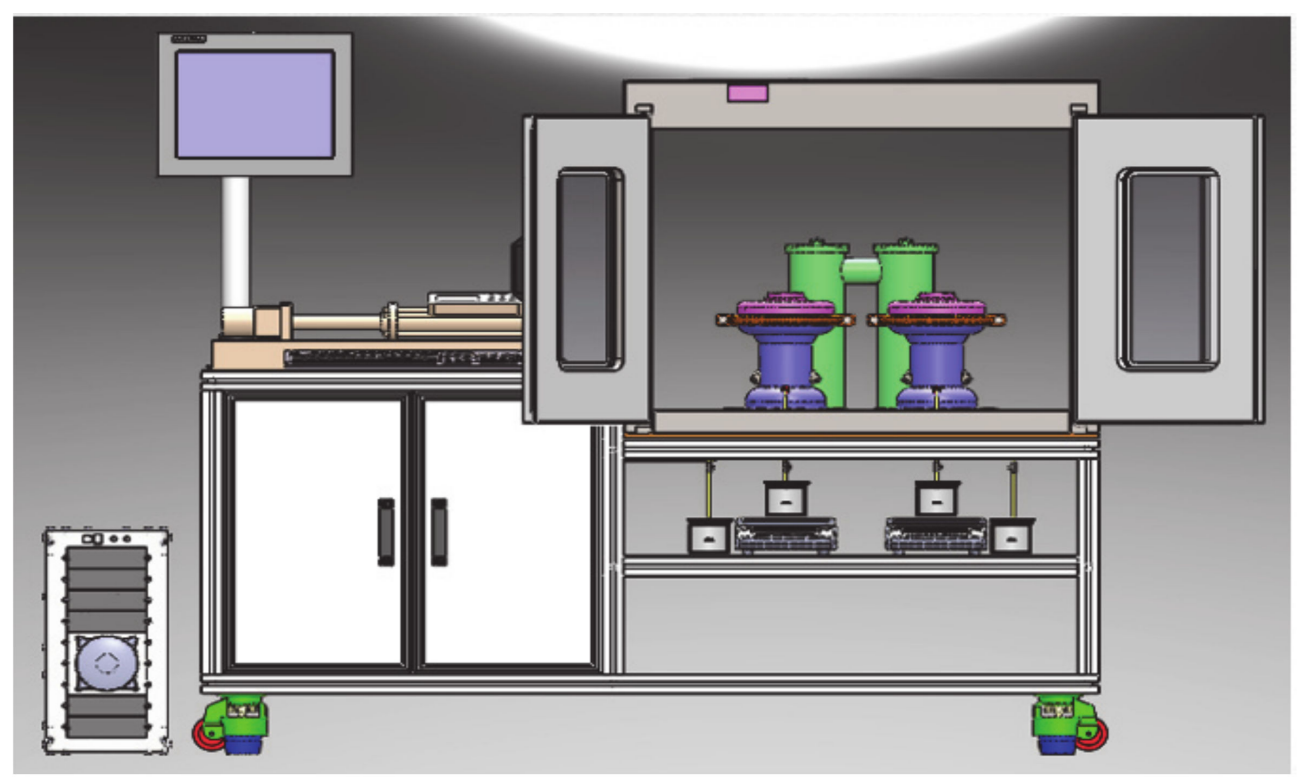

Figure 1. Multifunctional swelling permeability test system.

\subsection{Testing Materials and Specimen Preparation}

The studied materials were densely compacted mixtures of GMZ Na-bentonite and quartz sand with a dry mass ratio (80:20). Some geotechnical and mineralogical properties are summarized by Wen [28]. The bentonite was from Xinghe country, China, with $75.4 \%$ montmorillonite. The main cations were $\mathrm{Na}^{+}$and $\mathrm{Ca}^{2+}$. The quartz sand was from Jiulong Mining Company, Hanzhong city, China, with $99.82 \% \mathrm{SiO}_{2}$.

Bentonite is buffer/backfill material needed in high-level waste engineering barriers, and the high plasticity of bentonite affects the quality of buffer/backfill block. In the process of adding water for the sample preparation, soil agglomeration and uneven distribution of water content affect the quality of blocks. Traditional mixing of soil and liquid water results in the agglomeration of bentonite, adhesion to the container, and uneven distribution of water. In this experiment, water was added to bentonite in the form of solid ice powder to mix the mixture (ice-soil mixture method) (Figure 2). The ice-soil mixing method is less time consuming, causes less adherence to the container, and cause less water content to deviate the targets. The moisture content was controlled at $13 \%$. The mixtures with bentonite fractions of $80 \%$ were compacted in a mold, with samples $20 \mathrm{~mm}$ tall, a diameter of $61.8 \mathrm{~mm}$ at dry densities: $1.70,1.80$, and $1.9 \mathrm{~g} / \mathrm{cm}^{3}$. The compaction process was controlled at the vertical speed of $1 \mathrm{~mm} / \mathrm{min}$. Finally, the samples were unloaded and placed into the test setup. Twelve tests were carried out on the samples using four pore solutions (Table 1). 

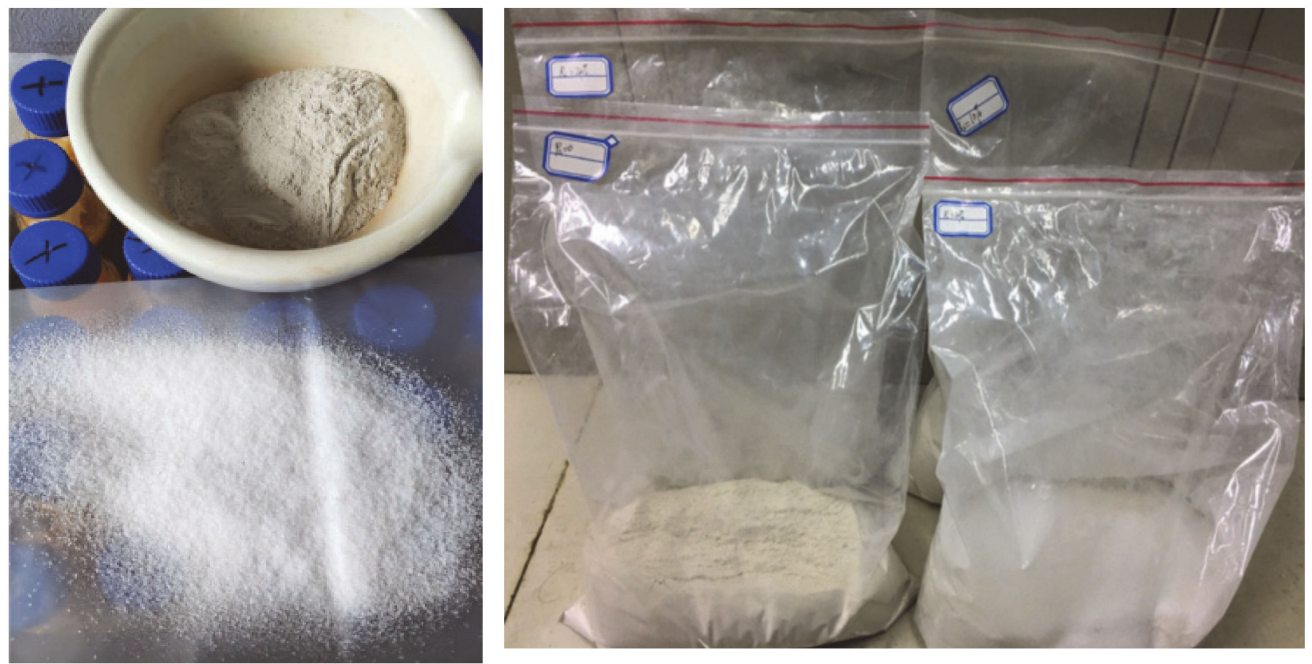

Figure 2. Testing materials.

Table 1. Samples tested and $\mathrm{pH}$ of the pore solutions used.

\begin{tabular}{cccc}
\hline No & Dry Density $\left(\mathbf{g} / \mathbf{c m}^{\mathbf{3}}\right)$ & Pore Solution & PH \\
\hline 1 & & DI water & 7 \\
2 & 1.70 & simulated Baishan groundwater & 8.2 \\
3 & & NaCl-Na $\mathrm{SO}_{4}$ solution & 7 \\
4 & NaOH solution & 13.8 \\
5 & DI water & 7 \\
6 & & simulated Baishan groundwater & 8.2 \\
7 & 1.80 & NaCl-Na $\mathrm{SO}_{4}$ solution & 7 \\
8 & & $\mathrm{NaOH}$ solution & 13.8 \\
9 & & DI water & 7 \\
10 & & simulated Baishan groundwater & 8.2 \\
11 & 1.90 & NaCl-Na $\mathrm{SO}_{4}$ solution & 7 \\
12 & & NaOH solution & 13.8 \\
\hline
\end{tabular}

DI-de-ionized water.

\subsection{Test Procedures}

The test process was controlled at $30^{\circ} \mathrm{C}$ with DI water. First, the densely compacted GMZ bentonite-sand mixture sample and the mold was put into the base of the testing apparatus. A permeable stone was placed at both ends of the sample. Stainless steel permeable partition plates were put on the top and bottom of permeable stones. Then the two valves were turned on, and DI water was injected through a valve. The valve was turned off after the air-bubbles were exhausted. DI water was poured into the specimen under the force of $0.1 \mathrm{MPa}$. The change in swelling pressure with time and the volume of DI water implanted into the sample was recorded. The sample was considered to be saturated when the water inlet and swelling pressure were stable. For tests with $\mathrm{NaOH}$ solution of $\mathrm{pH}=13.8$, after the air-bubbles in the test system were exhausted, $\mathrm{NaOH}$ was injected into the specimen through a water-alkali solution converter at a pressure of $0.1 \mathrm{MPa}$ by the pressure-volume controller.

The hydraulic conductivity test was employed until a steady flow was reached. The osmotic pressure was raised to $2.5 \mathrm{MPa}$ and remained at that value. When there was a stable seepage liquid flowing out, the timing measurement was started. The drained penetrant was collected in a $50 \mathrm{~mL}$ volumetric flask, and the amount of water leakage was collected and recorded every $12 \mathrm{~h}$. When the water yield measured was stable, the hydraulic conductivity test at $30^{\circ} \mathrm{C}$ was considered to be over. When the confining pressure, the pressure gradient, and the seepage velocity passing through the sample were stable, 
the seepage velocity through the sample reached a certain stable velocity. Darcy's law can be applied to this situation for calculating hydraulic conductivity.

\subsection{Specimen Cutting}

For further analysis of mineralogical and microstructure, the saturated samples were taken out of the stainless steel pressure chamber and cut. Figure 3 displays the diagram of the specimen dissection, which underwent the multifunctional swelling permeability tests. The specimen was cut at II into approximately $10 \mathrm{~mm}$ pieces, and then freeze-dried for the FESEM test. A part of the powder was obtained by cleaning, drying, and grinding, which was used for XRD mineralogical analysis. A new specimen was packaged and the former steps repeated for the tests with other solutions.
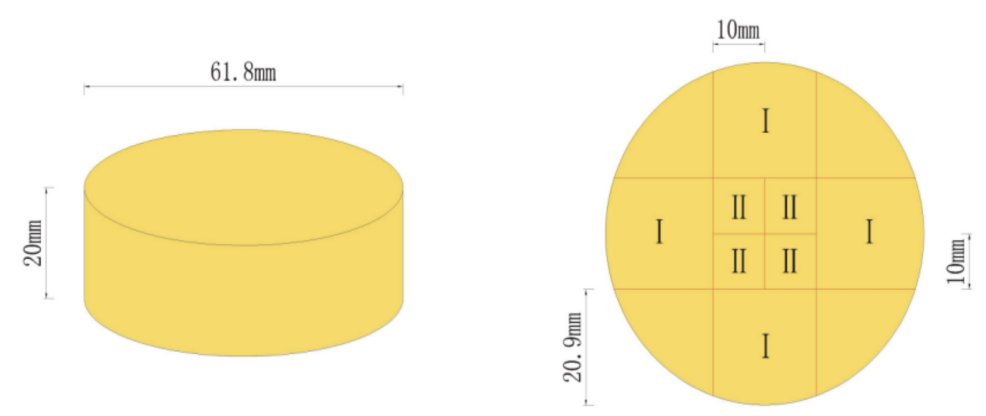

Figure 3. Diagram of the specimen cutting after the multifunctional swelling permeability tests.

\section{Experimental Results and Discussion}

\subsection{Effects of Different Solution Infiltration on Swelling Pressure of Bentonite-Sand Mixtures}

The expansion pressure is the maximum pressure applied by the soil under the condition of lateral limit to absorb water sufficiently, so that vertical expansion does not occur. Figure $4 \mathrm{a}-\mathrm{c}$ gives that the history curves of the expansion pressure of the specimens (dry densities $\mathrm{a}=1.7 \mathrm{~g} / \mathrm{cm}^{3}, \mathrm{~b}=1.8 \mathrm{~g} / \mathrm{cm}^{3}, \mathrm{c}=1.9 \mathrm{~g} / \mathrm{cm}^{3}$ ) in contact with different solutions as a function of time. It is observed that the expansion pressure of specimens increased with time in different solution media. For the specimens of infiltrating solutions (DI water, simulated Baishan groundwater, $\mathrm{NaCl}-\mathrm{Na}_{2} \mathrm{SO}_{4}$ solutions), the test results showed that the time-history curve of swelling pressure experienced the rapid swelling stage, the slow expansion stage, and the stable expansion stage. In the rapid swelling stage, with the beginning of hydration, the expansion pressure increased sharply and, after approximately $48 \mathrm{~h}$, achieved the first maximum value, basically reaching $85 \%$ of the final expansion pressure. In the slow expansion stage, the swelling pressure presented a steady increase and lasted about $24 \mathrm{~h}$. In the stable expansion stage, the swelling pressure continued to increase and reached the ultimate swelling pressure at about $120 \mathrm{~h}$ keeping a stable state. For the specimens of $\mathrm{NaOH}$ solutions (Figure 4d), the development of swelling pressure also experienced three stages. For the first stage, the pressure grew rapidly and, after about $72 \mathrm{~h}$, reached the maximum swelling pressure. For the second stage, the swelling pressure presented a slowly decreasing tendency, which lasted about $48 \mathrm{~h}$. For the third stage, expansion pressure maintained a definite value. The swelling pressure presented by fabric re-arrangement was observed a decreasing tendency when the compacted GMZ bentonite-sand mixtures were infiltrated with $0.6 \mathrm{M} \mathrm{OH}^{-}$anions. This decreasing reaction is associated with the dissolution of montmorillonite and silicate minerals. The $\mathrm{OH}^{-}$anions not only directly dissolved montmorillonite but also reacted with its hydrolyzate and even formed non-expanding secondary minerals, and then the swelling capacity decreases [29]. This observation is consistent with the conclusions reported by [14] and [30]. Karnland et al. found that $0.1 \mathrm{M} \mathrm{NaOH}$ solution has no effect on expansion pressure, and $1.0 \mathrm{M}$ $\mathrm{NaOH}$ solution results in an obvious lessening of expansion pressure [14]. Herbert et al. observed a continuous deterioration in swelling pressure with the bentonites infiltrated in $\mathrm{NaOH}$ solutions [30]. 

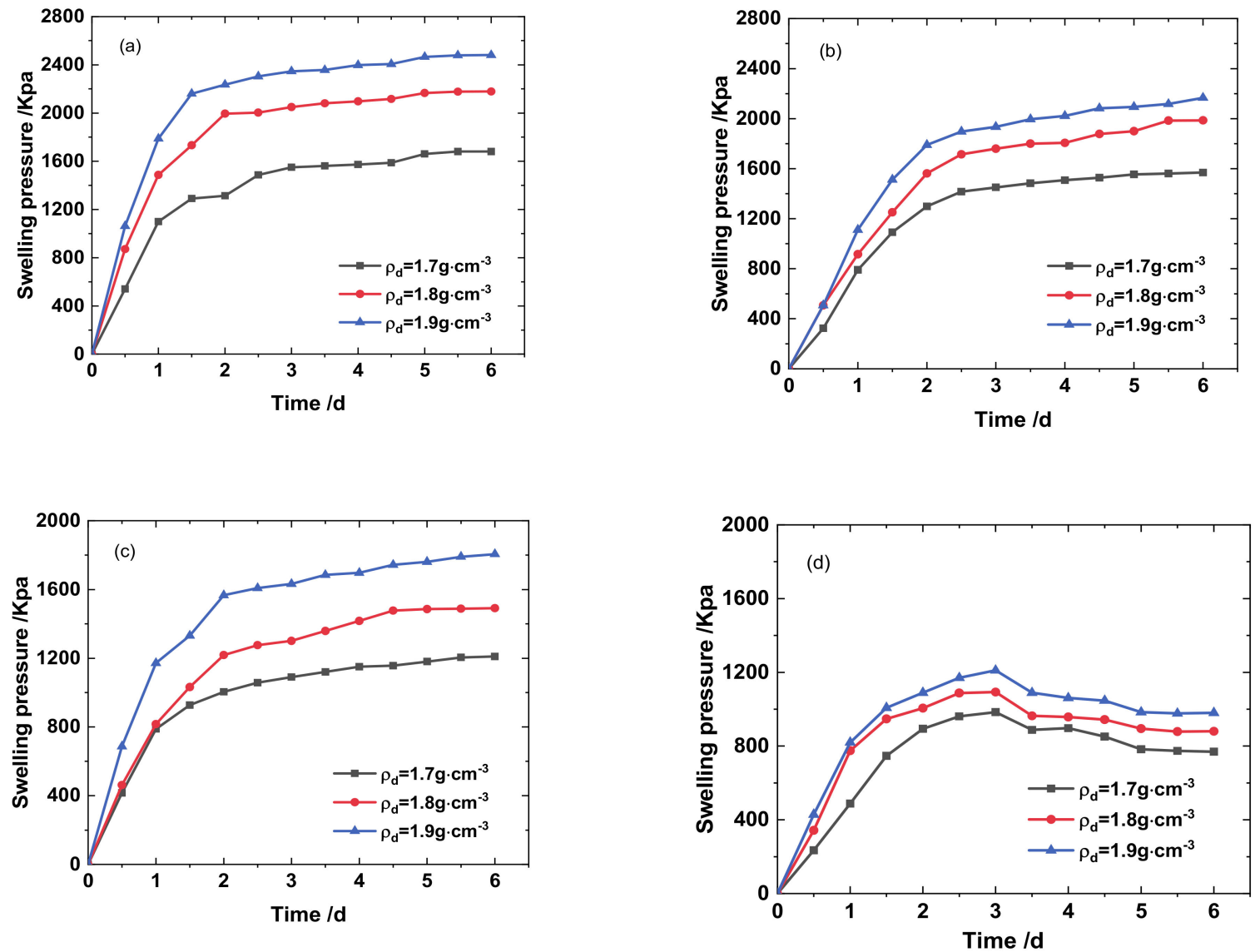

Figure 4. Relationship between swelling pressure and time of Gaomiaozi (GMZ) bentonite-sand mixtures: (a) DI—deionized water, (b) Baishan groundwater, (c) $\mathrm{NaCl}-\mathrm{Na}_{2} \mathrm{SO}_{4}$ solutions, (d) $\mathrm{NaOH}$ solutions.

Although the growth value of swelling pressure of each sample was different, the changing trend of swelling pressure of the other three pore solution samples was basically the same except for the $\mathrm{NaOH}$ solution. Under the same initial dry density (Figure 5a-c), the swelling pressure was largest under the infiltration of DI water and smallest under the $\mathrm{NaOH}$ solution. Specifically, for a given dry density $1.8 \mathrm{~g} / \mathrm{cm}^{3}$, relative to DI water, the expansion pressures were cut down by $0.69 \mathrm{MPa}$ and $1.3 \mathrm{MPa}$ for the specimens infiltrated with $\mathrm{NaCl}-\mathrm{Na}_{2} \mathrm{SO}_{4}$ and $\mathrm{NaOH}$ solutions, the expansion pressure reduced from $2.18 \mathrm{MPa}$ to $1.49 \mathrm{MPa}$ to $0.88 \mathrm{MPa}$. For the bentonite in the salt solution, the main reason why the expansion pressure decreased is that the cation in solution exchanged with that in montmorillonite, while in alkaline solution, the reason is that montmorillonite was dissolved. Alkali metal ion solution and alkali solution can reduce the swelling pressure, and the weakening degree is strengthened with the increasing temperature and $\mathrm{pH}$ value [31].

The variation of maximum swelling pressure and dry density for hyper-alkaline and hyper-salinity specimens with a $20 \%$ sand addition ratio is shown in Figure 6 . The maximum swelling pressure increased exponentially in the wake of the increase in dry density. This relational expression signifies that dry density can impel the max swelling pressure. For a given $\mathrm{NaCl}-\mathrm{Na}_{2} \mathrm{SO}_{4}$ concentration, the swelling pressure of $1.70 / 1.80 / 1.90 \mathrm{~g} / \mathrm{cm}^{3}$ specimens increased from 1.21 MPa to $1.49 \mathrm{MPa}$ to $1.81 \mathrm{MPa}$. For a given $\mathrm{NaOH}$ concentration, the swelling pressure of $1.70 / 1.80 / 1.90 \mathrm{~g} / \mathrm{cm}^{3}$ specimens increased from $0.98 \mathrm{MPa}$ to $1.09 \mathrm{MPa}$ to $1.21 \mathrm{MPa}$. 

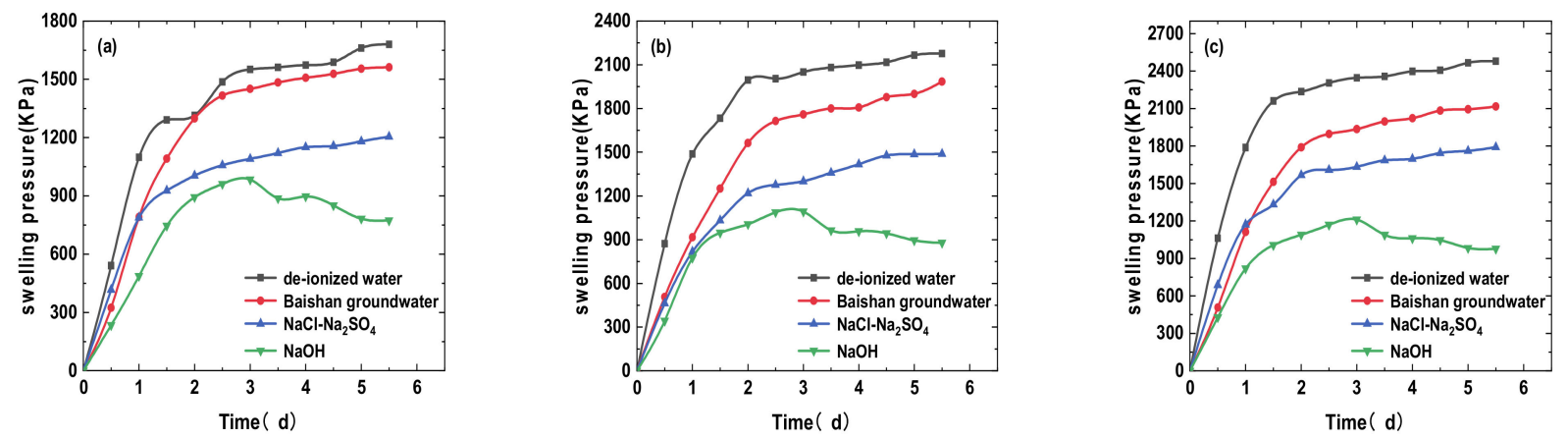

Figure 5. Influence of different solutions on the swelling pressure: (a) dry density of $1.7 \mathrm{~g} / \mathrm{cm}^{3},(\mathbf{b})$ dry density of $1.8 \mathrm{~g} / \mathrm{cm}^{3}$, (c) dry density of $1.9 \mathrm{~g} / \mathrm{cm}^{3}$.
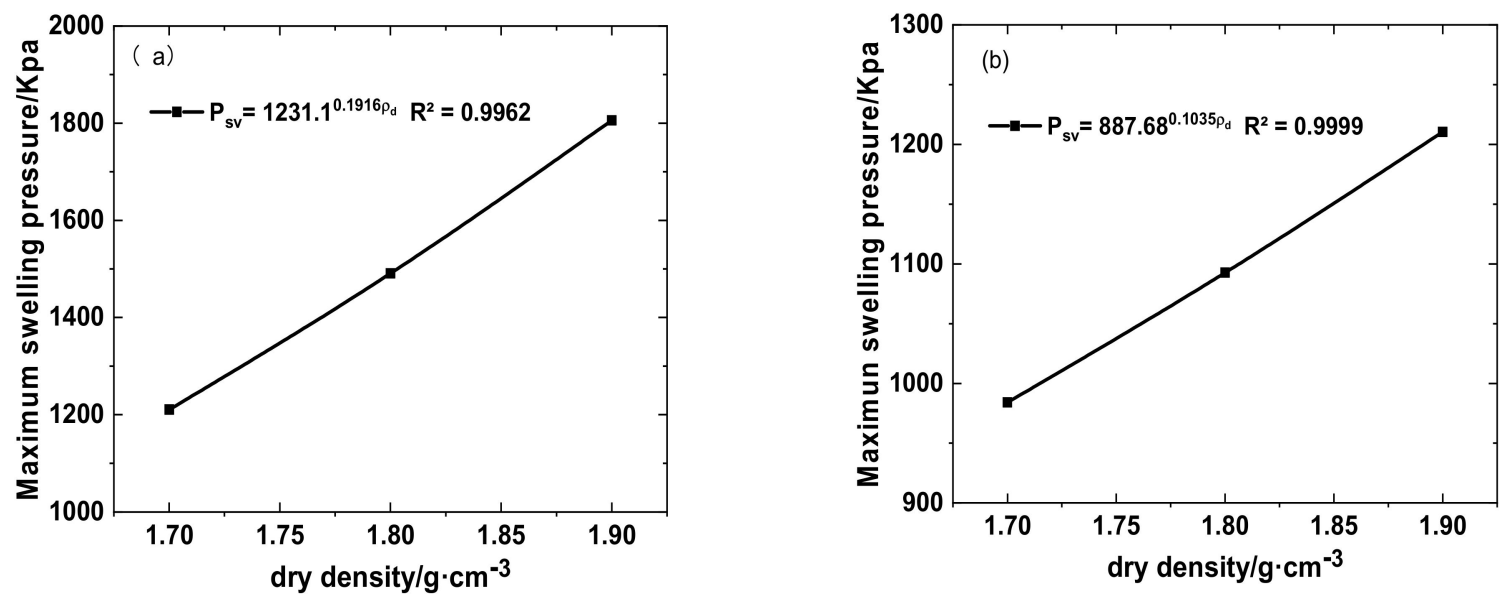

Figure 6. Maximum swelling pressure vs. dry density of samples: (a) $0.6 \mathrm{~mol} / \mathrm{L} \mathrm{NaCl}-\mathrm{Na}_{2} \mathrm{SO}_{4}$, (b) $0.6 \mathrm{~mol} / \mathrm{L} \mathrm{NaOH}$.

\subsection{Effects of $p H$ Value on Mineralogy}

The mineralogical characterization of samples with different solutions experienced tests are shown in Figure 7 (the dry density was $1.7 \mathrm{~g} / \mathrm{cm}^{3}$ ), using an X'PertPro X-ray diffractometer of Southwest University of Science and Technology in China, which operates at $40 \mathrm{kV}$ and $100 \mathrm{~mA}$, was employed in this study. XRD test of the sample was carried out with CuKa radiation $(\lambda=0.154 \mathrm{~nm})$, and the scanning range was $3 \sim 80^{\circ}$. The $2 \theta-$ scan speed was $4^{\circ} \min ^{-1}$, and the scanning mode was continuous scanning. No obvious mineralogical variation was detected in the mixture's reaction with different solutions in Figure 7. Compared to permeation of DI water, the crest value strength of montmorillonite in the mixtures going through the permeation of $\mathrm{NaCl}-\mathrm{Na}_{2} \mathrm{SO}_{4}$ and $\mathrm{NaOH}$ solution was relatively low.

After the samples were permeated with $0.6 \mathrm{M} \mathrm{NaCl}-\mathrm{Na}_{2} \mathrm{SO}_{4}$ and $\mathrm{NaOH}$ solution, the diffraction peak intensity of montmorillonite decreased significantly from $5463 \mathrm{cps}$ to $4378 \mathrm{cps}$ and $3565 \mathrm{cps}$, respectively, which signified a decline of the montmorillonite level of mixtures by permeated hyper-alkaline and hyper-salinity solutions. Figure 7 shows the characteristic peak layer spacing of montmorillonite changed in different degrees after the samples were permeated with ionic solution. The peak value of diffraction strength of montmorillonite decreased with increasing concentration of pore fluid, which suggests that montmorillonite dissolved with high salt and high alkali bring about the expansion pressure decrease. This explanation is supported by Sanchez et al. [32]: more dissolution of smectites occurred at a higher temperature and higher $\mathrm{pH}$ of alkali solution. It is also in line with the conclusion that after contact with potassium hydroxide solution, the crest value strength of montmorillonite reduced greatly [33]. Xiang et al. discovered that smectites in bentonite dissolved continuously under the long-term erosion of $\mathrm{NaOH}$ solution, causing 
a decline of swelling pressure [34]. In this study, the formation of new minerals was not detected. Only the content of montmorillonite decreased gradually, which may be related to the lower temperature or the short reaction time.

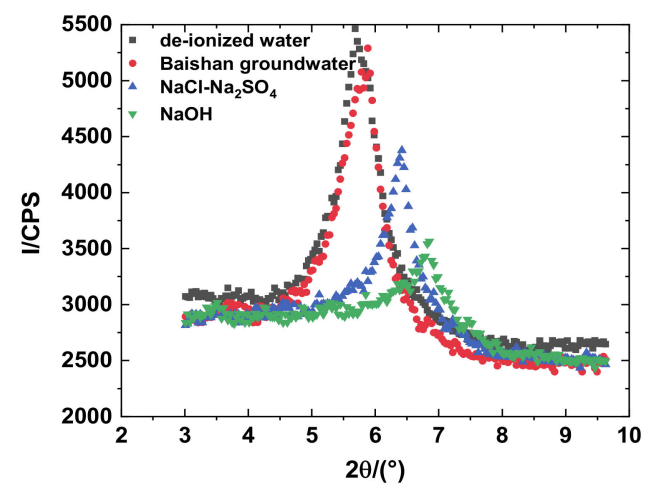

Figure 7. X-ray diffraction (XRD) patterns semctite composition of specimens infiltrated by different solutions.

\subsection{Solution Infiltration Influences on Saturated Permeability Coefficient}

The permeability coefficient is the unit flow rate under the unit hydraulic gradient, indicating the difficulty of fluid through the pore skeleton. The development of the permeability coefficient of mixtures with time at different dry densities is revealed in Figure $8 \mathrm{a}-\mathrm{c}$. It can be seen that the bentonite-sand mixture's permeability and its dry density go hand in hand, and the permeability coefficient decreased in the wake of a dry density rise, which indicates that the dry density plays a leading function in affecting bentonite-sand mixture's permeability. The evolution of the solution on the permeability coefficient of samples first decreased and then tended to be stable. At the preliminary stage, the permeability coefficient decreased rapidly, and after reaching a certain value, the hydraulic conductivity tended towards stability at about $125 \mathrm{~h}$. This was mainly because the bentonite swelled first in the solution, blocking the pores in the soil. It may be owing to the clayey soil particles' action [35]. In fact, hydrous clayey soil particles may be moved by osmotic pressure, which can cause assemblage of clay particles in big apertures of the soil sample, and consequently reduce the permeability coefficient. After the test was carried out for a long time, the ions in the solution had a negative effect on the expansion of the bentonite, which resulted in no obvious changes in the hydraulic conductivity. Compaction to a high dry density means that the cross-section of macropores forming channels decreased, and the interconnectedness and the void ratio decreased, which indicates that the permeability coefficient reduces with the decrease in the void ratio. The viscous water film on the surface of clay, integrated with electric double-layers, provides resistance to pore water flow, making the conductivity of high-pressure compacted clay extremely low. The conclusion is in line with the findings received by Cheng et al. [36].

For specimen of $1.7 \mathrm{~g} / \mathrm{cm}^{3}$ dry density, the permeability coefficient changed from $6.87 \times 10^{-13} \mathrm{~m} / \mathrm{s}$ (with DI water) to $6.84 \times 10^{-13} \mathrm{~m} / \mathrm{s}$ (with Baishan groundwater) to $11.93 \times 10^{-13} \mathrm{~m} / \mathrm{s}$ (with $0.6 \mathrm{M} \mathrm{NaCl}-\mathrm{Na}_{2} \mathrm{SO}_{4}$ solutions) and $15.51 \times 10^{-13} \mathrm{~m} / \mathrm{s}$ (with $0.6 \mathrm{M}$ $\mathrm{NaOH}$ solutions), respectively. At the same concentration, different ionic solutions had different consequences on the permeability coefficient of mixed soil. For a specimen of $1.8 \mathrm{~g} / \mathrm{cm}^{3}$ dry density with $0.6 \mathrm{~mol} / \mathrm{L}$ concentration, the permeability coefficient with high salt and high alkali solution was $8.59 \times 10^{-13} \mathrm{~m} / \mathrm{s}$ and $13.8 \times 10^{-13} \mathrm{~m} / \mathrm{s}$, respectively. The high salt concentration in pore water caused the soft part of clay gel and microstructural particle network to coagulate, thus widening the voids and leading to the increase in average volumetric hydraulic conductivity. The results show that the osmotic solution with higher concentration, the greater the permeability coefficient. The conclusion is in line with the findings received earlier studies [37,38]. 

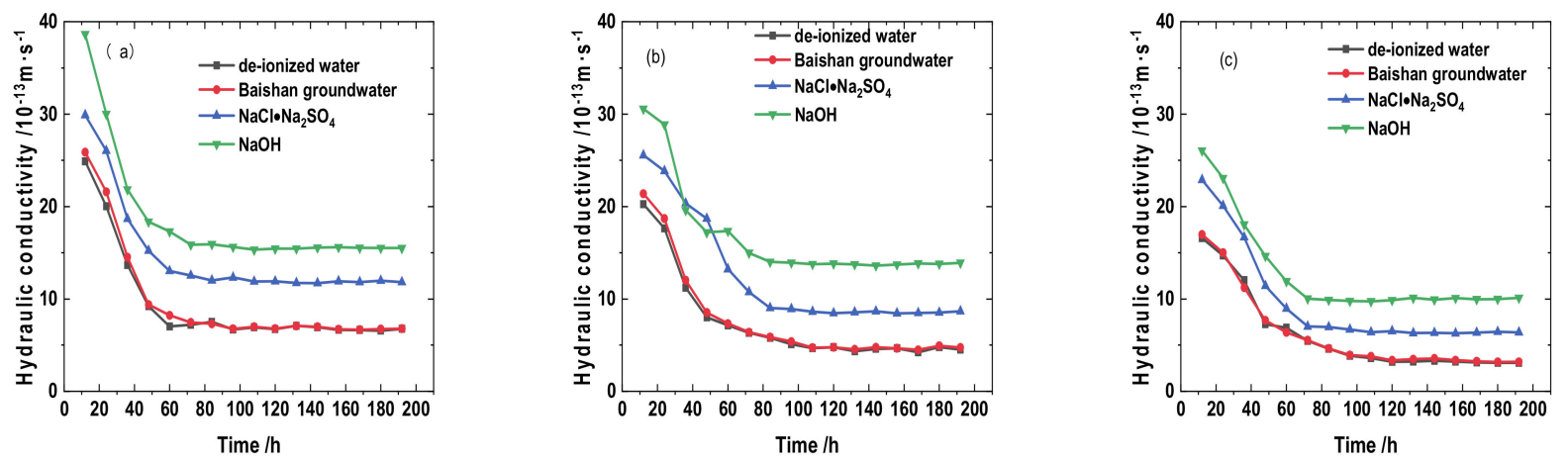

Figure 8. Influence of different solutions on the permeability coefficient of GMZ bentonite-sand mixtures: (a) dry density of $1.7 \mathrm{~g} / \mathrm{cm}^{3},(\mathbf{b})$ dry density of $1.8 \mathrm{~g} / \mathrm{cm}^{3}$, (c) dry density of $1.9 \mathrm{~g} / \mathrm{cm}^{3}$.

The hydraulic conductivity increased as the samples were permeated with $0.6 \mathrm{M}$ $\mathrm{NaCl}-\mathrm{Na}_{2} \mathrm{SO}_{4}$ and $\mathrm{NaOH}$ solution. This was consistent with the observations from the XRD test results- the amount of dissolved montmorillonite increased with the hyperalkaline and hyper-salinity (Figure 7). This dissolution resulted in the decrease in effective montmorillonite dry density. Moreover, the hydraulic conductivity of a sand-bentonite mixture increased with the decreasing dry density. This observation is consistent with the conclusions reported by Ref. [39].

\subsection{Characterization of Microstructure}

The field emission scanning electron microscope (FESEM) tests were conducted with an ULTRA 55 from Carl Zeiss AG for microstructure observation of mixtures after tests. Figure 9 presents the FESEM images of samples reacted with solutions at a dry density of $1.70 \mathrm{~g} / \mathrm{cm}^{3}$. From Figure $9 \mathrm{a}$, the results show that after saturated permeation with DI water, the basic sheet structure of montmorillonite remained unchanged. In the process of hydration, the pores between the crystal layers and in the aggregate of bentonite absorbed water and expanded. However, due to the volume limitation, the crystal layer and the particles could only expand into the pores between the aggregates, resulting in a decline in the number of big apertures and a rise in the number of small apertures, and the porosity size inclined to be well-distributed. Their contact boundaries decreased due to the pores between the aggregates filling with hydrated gel. The glossy wing-like smectites assemblage were formed after hydration; ultimately, the pores of the aggregates became smaller and well-distributed.

When the simulated Baishan groundwater penetrated the samples, the microstructure of the samples was almost unaffected (Figure 9b). The massive structure of montmorillonite was basically intact. There were a number of alary-like gel aggregates on the surface, but almost no big apertures were observed. Figure $9 \mathrm{c}$ shows that some fissures appeared in the specimens after reaction with the hyper-salinity solution $\left(\mathrm{NaCl}: \mathrm{Na}_{2} \mathrm{SO}_{4}=2: 1\right)$, and the surface of the sample became rough and produced some small particles, some layered gels could be distinctly distinguished on the surface of the sample. When the hyper-alkaline solution $(\mathrm{NaOH})$ was infiltrated, the microstructure of the specimens was greatly changed (Figure 9d). The dissolution and erosion of the wing-like montmorillonite aggregates were observed, and small splits and debris began to appear. More small aggregates of cracked fragments were produced. Compared with the specimens permeated by deionized water and hyper-alkaline solution, it was found that under the corrosion of hyper-alkaline solution, the pores of samples increased, and the increase in macropores was more obvious, which widened the infiltration path of the solution and improved the permeability coefficient of bentonite. 

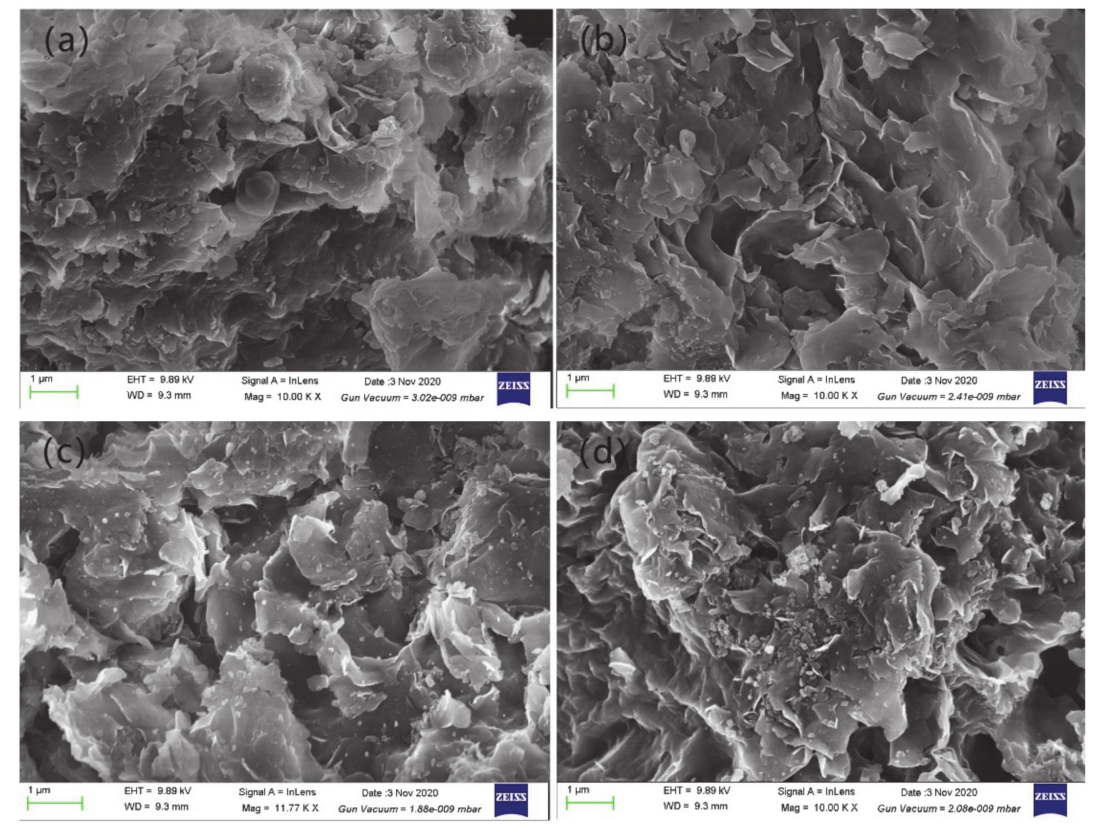

Figure 9. Field emission scanning electron (FESEM) photos of samples reacted with different solutions at a dry density of $1.70 \mathrm{~g} / \mathrm{cm}^{3}$ : (a) DI water, (b) Baishan groundwater, (c) $\mathrm{NaCl}-\mathrm{Na}_{2} \mathrm{SO}_{4}$ solutions, (d) $\mathrm{NaOH}$ solution.

\section{Conclusions}

Gaomiaozi bentonite has a high expansibility, special crystal interlayer structure, and ion exchange capacity. Adding sand into bentonite effectively changes its constructability and heat conductivity. Therefore, the bentonite-sand mixture is widely applied to the deep geological repository of HLW. Cement degradation may occur during the operation of the reservoir in the Beishan area, and the groundwater may reach a high $\mathrm{pH}$ value. The following conclusions are drawn:

(1) The swelling and hydraulic tests were carried out on GMZ bentonite-sand mixtures with different dry densities $\left(1.7,1.8\right.$, and $\left.1.9 \mathrm{~g} / \mathrm{cm}^{3}\right)$ and infiltrating solutions: DI water, simulated Baishan groundwater, $\mathrm{NaCl}-\mathrm{Na}_{2} \mathrm{SO}_{4}$ solution, and $\mathrm{NaOH}$ solution. Each solution had various chemical reactions with the mixtures, causing various swelling pressure (SWP) and mineralogy. The value of SWP was the maximum when infiltrated with DI water $(>2.5 \mathrm{MPa})$, decreased slightly in contact with simulated Baishan groundwater $(>2 \mathrm{MPa})$, and was the smallest when infiltrated with $\mathrm{NaOH}$ solutions $(<1 \mathrm{MPa})$. The SWP of the mixture increased with time in various solution media, and the history curve of SWP experienced three stages. The influence of $\mathrm{NaOH}$ solution on the SWP of the mixtures primarily happened in the second stage. The evolution of the solution on the hydraulic conductivity of samples first decreased and then tended to be stable, and the permeability coefficient decreased with dry density rise. The concentration of ionic solution had a significant effect on the permeability coefficient of mixed soil, which was greater than DI water.

(2) XRD test results indicated that after the samples were permeated by ionic solution, and the characteristic peak layer spacing of montmorillonite changed in different degrees. The crest value of diffraction intensity of montmorillonite diminished with the increasing solution concentration, which indicates that montmorillonite dissolved with high salt and high alkali.

(3) The results of FESEM showed the denudation and breakage of montmorillonite aggregates and the formation of cracks. After hydration with deionized water and simulated Baishan groundwater, it was found that the layered montmorillonite structure was basically intact and smooth and had smooth wing-like montmorillonite aggregates with good shape characteristics. The wing-like montmorillonite aggre- 
gates at the surface might have blocked the pores. After hydration with hyper-alkaline and hyper-salinity solutions, lamellar montmorillonite had obvious lamellar dissolution traces, and the dissolution and denudation degree of hyper-alkaline was more serious than that of hyper-salinity. The integrity of the montmorillonite structural was seriously damaged. The increase in macropores was more obvious, which widened the permeability path of the solution and improved the permeability of bentonite.

Author Contributions: Y.-P.W. and Z.W. designed the overall framework and conceived the idea for this paper, Y.-P.W. and Y.Z. designed the experiments and analyzed the data, F.-C.Y. and B.-L.Z. provided some suggestions on the structure of the paper, and Y.-P.W., Y.Z., and Z.W. wrote the paper. All authors have read and agreed to the published version of the manuscript.

Funding: This research was funded by the National Natural Science Foundation of China (No. 41402248), Scientific Research Projects of Decommissioning Nuclear Facilities and Radioactive Waste Treatment of the State Administration of Science, Technology and Industry for National Defense (No. 20181521), Key Projects of Science and Technology Department of Sichuan Province (No. 2018SZ0298), PI Team Project of Nuclear Waste and Environmental Safety Collaborative Innovation Center of The Ministry of Education, Science and Technology Planning Project of Education Department of Sichuan Province (No. 16ZB0150), and the Longshan Talent Research Program of Southwest University of Science and Technology (Nos. 17LZX613, 18LZX638).

Institutional Review Board Statement: Not applicable.

Informed Consent Statement: Not applicable.

Data Availability Statement: Data sharing not applicable.

Acknowledgments: The authors would like to thank Ya-Dong Wu and Zhi-Qiang Zeng for their assistance in revising the manuscript.

Conflicts of Interest: The authors declare conflict of interest.

\section{References}

1. International Atomic Energy Agency IAEA. Geological Disposal Facilities for Radioactive Waste-Specific Safety Guide No. SSG-14. 2011. Available online: https:/ / www.iaea.org/publications/8535/geological-disposal-facilities-for-radioactive-waste (accessed on 15 July 2020).

2. Yoon, S.; Jeon, J.S.; Kim, G.Y.; Seong, J.H.; Baik, M.H. Specific heat capacity model for compacted bentonite buffer materials. Ann. Nucl. Energy 2019, 125, 18-25. [CrossRef]

3. Bossart, P.; Bernier, F.; Birkholzer, J.; Bruggeman, C.; Connolly, P.; Dewonck, S.; Fukaya, M.; Herfort, M.; Jensen, M.; Matray, J.M.; et al. Mont Terri rock laboratory, 20 years of research: Introduction, site characteristics and overview of experiments. Swiss J. Geosci. 2017, 110, 3-22. [CrossRef]

4. Takeuchi, M.R.H.; Hasegawa, T.; McKinley, L.; Marquez, G.P.; Ishihara, K.N. What is suitable leadership for high-level radioactive waste (HLW) management. Sustainability 2020, 12, 8691. [CrossRef]

5. Komine, H.; Ogata, N. Experimental study on swelling characteristics of sand-bentonite mixture for nuclear waste disposal. Soils Found. 1999, 39, 83-97. [CrossRef]

6. Villar, M.V.; Lloret, A. Influence of temperature on the hydromechanical behaviour of a compacted bentonite. Appl. Clay Sci. 2004, 26, 337-350. [CrossRef]

7. Siddiqua, S.; Blatz, J.; Siemens, G. Evaluation of the impact of pore fluid chemistry on the hydromechanical behaviour of clay-based sealing materials. Can. Geotech. J. 2011, 48, 199-213. [CrossRef]

8. Rao, S.M.; Ravi, K. Influence of initial degree of saturation on swell pressures of compacted Barmer bentonite specimens. Ann. Nucl. Energy 2015, 80, 303-311. [CrossRef]

9. Jia, L.Y.; Chen, Y.G.; Ye, W.M.; Cui, Y.J. Effects of a simulated gap on anisotropic swelling pressure of compacted GMZ bentonite. Eng. Geol. 2019, 248, 155-163. [CrossRef]

10. Zhu, C.M.; Ye, W.M.; Chen, Y.G.; Chen, B.; Cui, Y.J. Influence of salt solutions on the swelling pressure and hydraulic conductivity of compacted GMZ01 bentonite. Eng. Geol. 2013, 166, 74-80. [CrossRef]

11. Chen, B.; Guo, J.X.; Zhang, H.X. Alteration of compacted GMZ bentonite by infiltration of alkaline solution. Clay Miner. 2016, 51, 237-247.

12. Ye, W.M.; Zheng, Z.J.; Chen, B.; Chen, Y.G.; Cui, Y.J.; Wang, J. Effects of $\mathrm{pH}$ and temperature on the swelling pressure and hydraulic conductivity of compacted GMZ01 bentonite. Appl. Clay Sci. 2014, 101, 192-198. [CrossRef] 
13. Studds, P.G.; Stewart, D.I.; Cousens, T.W. The effect of ion valance on the swelling behaviour of sodium bentonite. In Polluted and Marginal Land-96, Proceeding of the 4th International Conference on Re-Use of Contaminated Land and Landfills, London, UK, 2-4 July 1996; Engineering Technics Press: Edinburgh, Scotland, 2-4 July 1996; pp. 139-142.

14. Karnland, O.; Olsson, S.; Nilsson, U.; Sellin, P. Experimentally determined swelling pressures and geochemical interactions of compacted Wyoming bentonite with highly alkaline solutions. Phys. Chem. Earth 2007, 32, 275-286. [CrossRef]

15. Castellanos, E.; Villar, M.V.; Romero, E.; Lloret, A.; Gens, A. Chemical impact on the hydro-mechanical behaviour of high-density FEBEX bentonite. Phys. Chem. Earth Parts A/B/C 2008, 33, S516-S526. [CrossRef]

16. Lee, J.O.; Lim, J.G.; Kang, I.M.; Kwon, S. Swelling pressures of compacted Ca-bentonite. Eng. Geol. 2012, 129, 20-26. [CrossRef]

17. Sun, D.A.; Zhang, L. Swelling characteristics of Gaomiaozi bentonite saturated by salt solution and their prediction. Rock Soil Mech. 2013, 34, 2790-2795. (In Chinese)

18. Karnland, O.; Nilsson, U.; Weber, H.; Wersin, P. Sealing ability of Wyoming bentonite pellets foreseen as buffer material-Laboratory results. Phys. Chem. Earth Parts A/B/C 2008, 33, S472-S475. [CrossRef]

19. Zhang, H.Y.; Cui, S.L.; Zhang, M.; Jia, L.Y. Swelling behaviors of GMZ bentonite-sand mixtures inundated in $\mathrm{NaCl}^{-\mathrm{Na}_{2} \mathrm{SO}_{4}}$ solutions. Nucl. Eng. Des. 2012, 242, 115-123. [CrossRef]

20. Nakayama, S.; Sakamoto, Y.; Yamaguchi, T.; Akai, M.; Tanaka, T.; Sato, T.; Iida, Y. Dissolution of montmorillonite in compacted bentonite by highly alkaline aqueous solutions and diffusivity of hydroxide ions. Appl. Clay Sci. 2004, 27, 53-65. [CrossRef]

21. Alawaji, H.A. Swell and compressibility characteristics of sand-bentonite mixtures inundated with liquids. Appl. Clay Sci. 1999, 15, 411-430. [CrossRef]

22. Cui, Y.J.; Tang, A.M.; Qian, L.X.; Ye, W.M.; Chen, B. Thermal-mechanical behaviour of compacted GMZ bentonite. Soils Found. 2011, 51, 1065-1074. [CrossRef]

23. Bag, R.; Rabbani, A. Effect of temperature on swelling pressure and compressibility characteristics of soil. Appl. Clay Sci. 2017, 136, 1-7. [CrossRef]

24. Neaman, A.; Pelletier, M.; Villieras, F. The effects of exchanged cation, compression, heating and hydration on textural properties of bulk bentonite and its corresponding purified montmorillonite. Appl. Clay Sci. 2003, 22, 153-168. [CrossRef]

25. Yamaguchi, T.; Sakamoto, Y.; Akai, M.; Takazawa, M.; Iida, Y.; Tanaka, T.; Nakayama, S. Experimental and modeling study on long-term alteration of compacted bentonite with alkaline groundwater. Phys. Chem. Earth Parts A/B/C 2007, 32, 298-310. [CrossRef]

26. Alfatlawi, T.J.M.; Alkafaji, S.S. Investigation of groundwater pollution minimization using compacted bentonite barriers. KSCE J. Civ. Eng. 2019, 23, 507-512. [CrossRef]

27. Balagosa, J.; Yoon, S.; Choo, Y.W. Experimental investigation on small-strain dynamic properties and unconfined compressive strength of gyeongju compacted bentonite for nuclear waste repository. KSCE J. Civ. Eng. 2020, 24, 2657-2668. [CrossRef]

28. Wen, Z.J. Physical property of China's buffer material for high-level radioactive waster repositories. Chin. J. Rock Mech. Eng. 2006, 25, 794-800. (In Chinese)

29. Liu, L.N.; Chen, Y.G.; Ye, W.M.; Cui, Y.J.; Wu, D.B. Effects of hyperalkaline solutions on the swelling pressure of compacted Gaomiaozi (GMZ) bentonite from the viewpoint of $\mathrm{Na}^{+}$cations and $\mathrm{OH}^{-}$anions. Appl. Clay Sci. 2018, 161, 334-342. [CrossRef]

30. Herbert, H.J.; Kasbohm, J.; Sprenger, H.; Fernandez, A.M.; Reichelt, C. Swelling pressures of MX-80 bentonite in solutions of different ionic strength. Phys. Chem. Earth Parts A/B/C 2008, 33, S327-S342. [CrossRef]

31. Ye, W.M.; Zheng, Z.J.; Chen, B.; Chen, Y.G. Progress of research on the influence of alkaline cation and alkaline solution on bentonite properties. World Nucl. Geosci. 2011, 28, 221-227. (In Chinese)

32. Sanchez, L.; Cuevas, J.; Ramirez, S.; Leon, D.R.D.; Fernandez, R.; Villa, R.V.D.; Leguey, S. Reaction kinetics of FEBEX bentonite in hyperalkaline conditions resembling the cement-bentonite interface. Appl. Clay Sci. 2006, 33, 125-141. [CrossRef]

33. Bauer, A.; Velde, B. Smectite transformation in high molar KOH solutions. Clay Miner. 1999, 34, 259-273. [CrossRef]

34. Xiang, G.S.; Xu, Y.F.; Wang, Y.; Fang, Y. Change Law of the Swelling Deformation of GMZ Bentonite Corroded by Alkaline Pore Water. J. Shanghai Jiao Tong Univ. 2018, 52, 141-146. (In Chinese)

35. Ye, W.M.; Wan, M.; Chen, B.; Chen, Y.G.; Cui, Y.J.; Wang, J. Temperature effects on the unsaturated permeability of the densely compacted GMZ01 bentonite under confined conditions. Eng. Geol. 2012, 126, 1-7. [CrossRef]

36. Cheng, G.; Zhu, H.H.; Wen, Y.N.; Shi, B.; Gao, L. Experimental investigation of consolidation properties of nano-bentonite mixed clayey soil. Sustainability 2020, 12, 459. [CrossRef]

37. Studds, P.G.; Stewart, D.I.; Cousens, T.W. The effects of salt solutions on the properties of bentonite-sand mixtures. Clay Miner. 1998, 33, 651-660. [CrossRef]

38. Mishra, A.K.; Ohtsubo, M.; Li, L.Y.; Higashi, T.; Park, J. Effect of salt of various concentrations on liquid limit and hydraulic conductivity of different soil-bentonite mixtures. Environ. Geol. 2009, 57, 1145-1153. [CrossRef]

39. Wang, Z.; Zhou, H.T.; Yi, F.C.; Niu, S.J.; Ma, P.J. Research on permeability of high compacted sand-bentonite mixtures as buffer material. Sci. Technol. Eng. 2017, 17, 231-235. (In Chinese) 